\title{
ANALISIS KECELAKAAN PADA KESELAMATAN DAN KESEHATAN KERJA (K3) PADA PROYEK APARTEMEN PORIS 88 TANGGERANG
}

\author{
Oleh : \\ Wiratna Tri Nugraha, \\ Dessi Hayyatun Aini \\ Fakultas Teknik Jurusan Teknik Sipil \\ Universitas Suryakancana
}

\begin{abstract}
ABSTRAK
Dengan melaksanakan penerapan K3 di dalam pekerjaan konstruksi akan terwujud perlindungan terhadap seluruh SDM yang terkait dalam pekerjaan konstruksi dari resiko kecelakaan kerja dan penyakit akibat kerja yang terjadi pada waktu melakukan pekerjaan di tempat kerja. Pelaksanaan K3 diharapkan akan tercipta tempat kerja yang aman, sehat, nyaman, dan tenaga kerja produktif. Pada kasus proyek pembangunan Apartement Poris 88 Tangerang, dimana PT. Nusantara Almasia Tangerang selaku Owner, PT. Gading Megah Jaya Jakarta Timur selaku kontraktor, dan PT. Cipta Sukses Jakarta Utara selaku konsultan melaksanakan kegiatan proyek tersebut dari Juli 2015 sampai Juni 2016 pada T ahap I- III. Proyek ini memperkerjakan staf karyawan 25 orang dan jumlah pekerja \pm 150 orang. Penerapan dan proses K3 SDM, K3 alat material, dan K3 lingkungan proyek, pada Proyek Apartement Poris 88 Tangerang berlangsung secara cukup baik.

Faktor-faktor yang mempengaruhi Penerapan Keselamatan Dan Kesehatan Kerja (K3) pada Proyek Apartement Poris 88 Tangerang antara lain:

Kecelakaan yang terjadi pada Proyek Apartemen Poris 88 Tangerang diantaranya adalah luka kecil seperti tertusuk paku, tergores dan luka berat terkena zat additif dan terkena kaitan bucket.

Dari penelitian tersebut penyusun mendapatkan kesimpulan bahwa Keselamatan Dan Kesehatan Kerja (K3) pada Proyek Apartement Poris 88 Tangerang tidak begitu baik di karenakan kelalaian pekerja yang tidak begitu mematuhi peraturan yang sudah di buat. Maka di harapkan para pekerja lebih berhati - hati dan APD di gunakan dengan baik.
\end{abstract}

Kata kunci : K3, kecelakaan, proyek, apartemen.

\section{A. PENDAHULUAN}

Dalam pekerjaan konstruksi, keselamatan dan kesehatan kerja (K3) sangat penting. Oleh karena itu perlu dilaksanakan penerapan K3 tersebut di dalam pekerjaan konstruksi, guna peningkatan kualitas tenaga kerja dan peran sertanya dalam pekerjaan konstruksi dengan meningkatkan perlindungan.

Pada kasus proyek pembangunan Apartement Poris 88 Tangerang, dimana PT. Nusantara Almasia Tangerang selaku Owner, PT. Gading Megah Jaya Jakarta Timur selaku kontraktor, dan PT. Cipta Sukses Jakarta Utara selaku konsultan melaksanakan kegiatan proyek tersebut dari Juli 2015 sampai Juni 2016 pada Tahap I-III.Sistematika penulisan laporan ini, adalah sebagai berikut:

Keselamatan kerja adalah keselamatan yang bertalian dengan mesin, pesawat, alat kerja, bahan, dan proses pengolahannya, landasan tempat kerja dan lingkungannya serta cara-cara melakukan pekerjaan (Sumakmur, 1993).

Menurut Sumakmur (1976) Kesehatan kerja merupakan spesialisasi ilmu kesehatan/kedokteran beserta prakteknya yang bertujuan agar pekerja/ memperoleh derajat kesehatan setinggitingginya baik fisik, mental maupun sosial dengan usaha preventif atau kuratif terhadap penyakit/ gangguan kesehatan yang diakibatkan oleh faktor pekerjaan dan lingkungan kerja serta terhadap penyakit umum. Kecelakaan Kerja (accident) adalah suatu kejadian atau peristiwa yang tidak diinginkan yang merugikan terhadap manusia, merusak harta benda atau kerugian terhadap proses. Kerugian-kerugian yang disebabkan oleh kecelakaan dapat berupa banyak hal yang mana telah dikelompokkan menjadi 5, yaitu :

1. Kerusakan

2. Kekacauan organisasi

3. Keluhan, kesakitan dan kesedihan

4. Kelainan dan cacat

5. Kematian

Ilmu Keselamatan dan Kesehatan Kerja (K3) yang merupakan bagian dari Ilmu Kesehatan Masyarakat adalah ilmu dan seni dalam pengelolaan bahaya (antisipasi, rekognisi, evaluasi dan pengendalian) di tempat kerja yang berpotensi menurunkan derajat kesehatan dan 
kesejahteraan pekerja. Dengan lingkungan kerja Indonesia ( GSI 3 ) yang berada di Jalan Raya Bandung KM. 08 s/d 11 menimbulkan bangkitan dan tarikan yang cukup besar pada jalan tersebut. Tata guna lahan yang kompleks di sepanjang jalan juga menimbulkan masalah cukup besar yang dapat memberikan dampak yang besar untuk kemacetan di ruas jalan tersebut. Keberadaan Pabrik PT. Pou Yuen Indonesia ( GSI 3 ) dapat menimbulkan masalah yang lebih kompleks sehingga menambah tingkat kemacetan pada ruas Jalan Raya Bandung khususnya di KM.08 s/d KM.11. yang aman dan sehat maka produktifitas perusahaan akan meningkat dan menunjang kelangsungan bisnis perusahaan tersebut. Selain itu, tuntutan regulasi nasional dan internasional mewajibkan perusahaan untuk menerapkan K3 di tempat kerja sehingga implementasi K3 di tempat kerja menjadi sangat penting.

\section{B. METODOLOGI PENELITIAN}

\section{Alur Penelitian}

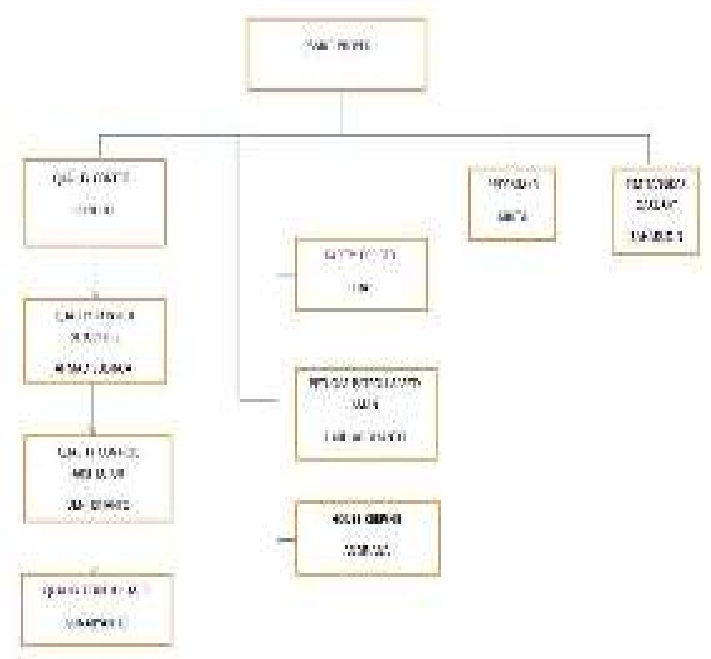

Gambar 1. Alur Penelitian

Ruang lingkup hyperkes dapat dijelaskan sebagai berikut (Rachman, 1990) :

Kesehatan dan keselamatan kerja diterapkan di semua tempat kerja yang di dalamnya melibatkan aspek manusia sebagai tenaga kerja, bahaya akibat kerja dan usaha yang dikerjakan.

1. Jatuh dari tetingian yang berbeda

2. Jatuh dari ketinian yang sama

3. Kejatuhan benda ( berat,keras,runcing, tajam dll )

4. Tersentuh benda panas

5. Tersentuh aliran listrik

6. Terbentur

7. Terbakar

8. Tersiram cairan panas, uap panas, debu, gas.
9. Keracunan bahan kimia, gas

10. Terjerat

11. Tertimpa ledakan

12. Tertusuk, terisris, tergores, ( benda tajam runcing )

13. Terpapar radioaktif

14. Dan lai-lain ( yang mungkin bertambah sesuai dengan kemajuan tehnologi, cara kerja dan pemakayan bahan.

Kasus-kasus kecelakaan yang terjadi di luar negeri umumnya adalah metode pelaksanaan konstruksi yang kurang tepat mengakibatkan gedung runtuh yang menewaskan banyak korban.

Sedangkan kasus yang terjadi di Indonesia umumnya terjadi karena lemahnya pengawasan pada proyek konstruksi. Kurang disiplin nya tenaga kerja dalam mematuhi ketentuan K3 dan kurang memadainya kuantitas dan kualitas alat perlindungan diri di proyek konstruksi.

Peralatan kerja bisa rusak atau tidak memadai, untuk itu perusahaan senantiasa harus memperhatikan kelayakan setiap peralatan yang dipakai dan melatih pegawai untuk memahami peralatan kerja tersebut.

Peralatan keselamatan kerja berfungsi untuk mencegah dan melindungi pekerja dari kemungkinan mendapatkan kecelakaan kerja Jaminan Sosial Tenaga Kerja (JAMSOSTEK) adalah suatu perlindungan bagi tenaga kerja dalam bentuk santunan berupa uang sebagai pengganti sebagian dari penghasilan yang hilang atau berkurang dan pelayanan sebagai akibat peristiwa atau keadaan yang dialami oleh tenaga kerja berupa kecelakaan kerja, sakit, hamil, bersalin, hari tua, dan meninggal dunia

\section{PEMBAHASAN}

Dalam bab ini yang akan dibahas resiko yang terjadi dalam proses pekerjaan struktur finishing dan ME dan akan penanggulangan terhadap kecelakaan .

Langkah pertama dalam proses resiko di lapangan adalah melakukan identifikasi bahaya tempat kerja atau tempat yang berpeluang mengalami kerusakan. Hal yang harus di perhatikan adalah bahaya akibat pekerjaan tidak saja terjadi pada saat kejadian, tetapi bisa juga terjadi dalam kurun waktu yang lama.

a. Pekerjaan Struktur Bawah

Pada pekerjaan Apartemen Poris 88 Tangerang terdapet resiko pada struktur bawah diantara ialah :

1. Hujan yang dapat menggenangi area pekerjaan

2. Kondisi tanah yang tidak teduga

3. Pergerakan tanah akibat galian tanah yang dapat mempengaruhi bangunan sekitar 
Upaya pencegahan dari resiko struktur bawah ialah :

1. Memakai helm safety

2. Memakai sarung tangan karet pada saat pengecoran

3. Memakai sarung tangan

4. Memakai rompi

5. Memakai baju panjang

6. Memakai celana panjang

b. Pekerjaan Struktur Atas

Pada pekerjaan Apartemen Poris 88 Tangerang terdapet resiko pada struktur atas diantara ialah:

1. Orang terjatuh dari crane

2. Kejatuhan benda dari atas

3. Crane amblas

Upaya pencegahan dari resiko struktur atas ialah :

1. Memakai helm safety

2. Memakai sepatu safety

3. Memakai baju panjang

4. Memakai celana panjang

5. Memakai sarung tangan karet pada saat pengerjaan coran

6. Memakai safety belt

7. Pasang lampu penerangan

8. Pasang railing pengaman

9. Pasang jaring pengaman (safety net)

10.Pasang rambu - rambu "awas kejatuhan benda dari atas

c. Pekerjaan Pabrikasi Dan Pemasangan Besi Beton

Pada pekerjaan Apartemen Poris 88 Tangerang resiko - resiko yang akan timbul pada pekerjaan pabrikasi dan pemasangan besi beton antara lain : 1. Kecelakaan akibat alat kerja, sperti alat potong, alat berbending

2. Tertimpa besi beton yang akan dipasang

3. Terperosok pada besi yang sudah di rakit

Resiko - resiko tersebut dapat di minimalisir apabila tenaga kerja sudah memakai peralatan keselamatan kerja seperti safety shoes, sarung tangan, dll.

d. Pekerjaan Bekisting

Pada pekerjaan bekisting yang harus diperhatikan adalah pemasangan bekisting pada bagian pengerjaan kolom yang harus lebih di perkuat karena rentan rusak yang diakibatkan karena tekanan material beton yang dimasukan. Resiko yang terjadi pada saat pengerjaan

bekisting pengerjaan bekisting terkena besi tulangan sehingga tangan tergores, pemasangan kawat bendrat tertusuk, agar menggunakan sarung tangan dan safety shoes. Dan resiko pada saat pembongkaran bekisting yaitu si pekerja terjepit, terluka dan tergores. Resiko yang sangat besar juga bisa terjadi pada saat pembongkaran si pekerja bisa terjatuh dari lantai atas karena tidak memakai safety belt.
Pekerjaan yang diindetifikasi di Proyek Apartemen Poris 88 Tangerang antara lain :

1. Tahapan persiapan

2. Tahapan pekerjaan struktur
a. Pekerjaan pembersihan lahan
b. Pekerjaan perataaan tanah
c. Pekerjaan pemagaran
d. Pekerjaan penggalian tanah
e. Pekerjaan pondasi tiang pancang
f. Pekerjaan basement
g. Pekerjaan kolom
h. Pekerjaan sloof/balok
i. Pekerjaan pelat
j. Pekerjaan atap
k. Pekerjaan tangga .
1. Pekerjaan dinding
m. Finishing
n. Masa pemeliharaan

3. Lingkungan proyek :
a. Kondisi lalu lintas proyek
b. Merokok
c. Aktivitas pekerjaan diatas
d. Aktivitas pekerjaan dibawah
e. Cuaca
f. Menempati barak pekerja

4. Keadaan darurat.

1. Pekerjaan Pembersihan Lahan

K3 pada pekerjaan pembersihan lahan proyek Apartemen Poris 88 Tangerang berjalan dengan kurang lancar karena resiko yang memungkinkan timbul pada kegiatan ini terjadi pada pekerjaan pembersihan lahan.

Adapun resiko yang terjadi kepada para pekerja yaitu pada saat pembabatan rumput terkena luka di tangan seharusnya para pekerja memakai sarung tangan agar tidak terkena luka b. Pekerjaan Perataan Tanah

Setelah pembersihan lahan maka dilakukan pekerjaan perataan tanah dengan memakai alat berat bulldozer, agar kontur tanah menjadi padat dan rata. Resiko yang terjadi pada saat perataan tanah terkena asap debu dari kendaraan atau dari tanah tersebut.

K3 pada pekerjaan perataan tanah proyek Poris

88 Tangerang berjalan dengan lancar dan tidak ada resiko kecelakaan pekerja.

\section{Pemagaran}

K3 pada pekerjaan pemagaran Proyek Poris 88

Tangerang tidak berjalan dengan lancar karena resiko yang memungkinkan terjadi selama lebih dari satu kali pada pekerjaan ini.

Resiko kecelakaan yang terjadi tertimpa material, terkena paku pada saat pemasangan pagar, 
iritasi dari seng tersebut bila berkarat, tergores pada ujung seng yang tajam, tergores dari lapisan kayu maka para pekerja di haruskan memakai sarung tangan dan sepatu safety.
3. Pembuatan
Bedeng/Barak,
Direksi Kit, Gudang

K3 dalam pembuatan fasilitas yang disediakan pada proyek ini mempunyai resiko yang memungkinkan terjadi. Resiko yang terjadi yaitu pada pemasangan triplek terkena palu pada pemasangan paku, terjatuh akibat memasang triplek di atas ketinggian, terkena goresan kayu pada saat pemasangan kayu. Maka cara pencegahan agar pekerja tidak terluka memakai sarung tangan.

Pada peraturan menteri tenaga kerja No. 05/MEN/1996 tentang Sistem Manajemen Keselemata Kerja (SMK3) tidak sesuai dengan apa yang ada dilapangan, karena APD yang digunakan tidak benar.

Pada Proyek Apartemen Poris 88 Tangerang, pihak perusahaan PT.GADING MEGAH JAYA membuat manajemen HSE. Perusahaan membuat manajemen tersebut untuk mencegah kecelakaan, melindungi lingkungan, sebagai kegiatan bisnis penting dan mempromosikan

budaya di mana semua karyawan dan subkontraktor berbagi komitmen. Manajemen HSE di siapkan bagi semua orang yang mungkin terlibat dengan pekerjaan diproyek, ini untuk memastikan mereka benar - benar menjalankan sesuai prosedur K3L (HSE).

\section{KESIMPULAN DAN SARAN}

\section{a. Kesimpulan}

\section{K3 SDM ( Sumber Daya Manusia )}

pengerjaan struktur pada Proyek Apartemen Poris 88 Tangerang pekerja proyek terkena kecelakaan kecil seperti tertusuk kawat bendrat, tergores pada pekerjaan besi dan tertusuk paku hingga terkena kecelakaan parah seperti terjepit pada saat pemasangan bucket dan terkena zat adiktif pada saat pengecoran

\section{K3 Material}

K3 material terhadap pengerjaan struktur pada Proyek Apartemen Poris 88 Tangerang, para pekerja seharusnya lebih menjaga material jangan di simpan di bukan tempatnya dan tertata dengan baik, termaksud lebih merhatikan kawat bendrat, besi tulangan, paku dan tang tidak berkarat, karena bisa terkena iritasi pada karatan tersebut, bila perlu besi tulangan di simpan di tempat ruangan khusus untuk material seperti gudang dan di pakai terpal agar tidak terkena air hujan.

\section{K3 Peralatan}

Pada K3 material Proyek Apartemen Poris 88 Tangerang menggunakan peralatan proyek seperti Tower crane, barcutter, barbender, concrette bucket, concrete pump . supaya peralatan ini di simpan pada tempatnya, seperti tower crane di tempatkan pada tempat yang sesuai dan kontur tanah di perhatikan agar tidak terjadi kecelakaan dan tower crane jatuh.

\section{Lingkungan Proyek}

Lingkungan Proyek Apartemen Poris 88 Tangerang pada saat penulis melaksanakan penelitian terlihat lingkungan proyek tidak cukup untuk memenuhi K3 yang berlaku sesuai dengan peraturan. Seperti yang telah dijelaskan pada bab IV, lokasi proyek tergenang oleh banjir yang menganggu aktivitas proyek. Kemudian kebersihan proyek kemudian pengamatan kebersihan di lapangan sangat mengecewakan, dimana banyak sampah - sampah yang berserakan seperti bekas punting rokok dan minuman yang di buang sembarangan oleh para pekerja di proyek. Safety tools

Pekerja di proyek ini kebanyakan tidak mematuhi aturan K3 kontruksi yang berlaku, safety tools yang sharusnya di pakai di biarkan begitu saja sehingga memakan korban di lapangan. Dari pihak pimpinan kontraktor maupun konsultan harus lebih meperhatikan dan memperingatkan agar pekerja lebih safety.

\section{b. Saran}

Proyek Poris 88 Tangerang seharusnya menerapkan kegiatan pengenalan,pengendalian dan pemahaman mengenai K3 kontruksi sebelum seluruh pekerja terjun ke lapangan. Proses tersebut di laksanakan di proyek ini hanya di lakukan seminggu tiga yang seharusnya di lakukan setiap hari.setiap pekerja di proyek mematuhi aturan k3 kontruksi yang berlaku pada saat bekerja yaitu memakai safety tools.

Pekerja di proyek ini kebanyakan tidak mematuhi aturan K3 kontruksi yang berlaku, safety tools yang sharusnya di pakai di biarkan begitu saja sehingga memakan korban di lapangan. Dari pihak pimpinan kontraktor maupun konsultan harus lebih meperhatikan dan memperingatkan agar pekerja lebih safety

\section{Pengendalian K3 SDM}

a. Pihak pimpinan secara tegas menerapkan K3 konstruksi bagi setiap pihak yang terkait dalam proyek tersebut untuk 
mentaati semua peraturan yang berlaku agar menghindari nilai kecelakaan yang dialami oleh para pekerja di lapangan.

b. Pihak yang telah di tunjuk sebagai penanggung jawab K3 konstruksi harus menjalankan tugasnya dengan baik seperti memperingatkan secara tegas kepada para pekerja agar memakai safety tools dan mematuhi peraturan yang berlaku di proyek. Pihak K3 kontruksi pun harus berani menegur pekerja yang tidak menuruti aturan.

c. Pekerja konstruksi harus menjalankan dan menaati peraturan K3 konstruksi yang berlaku.

\section{Pengendalian K3 Material}

a. Pihak kontraktor harus lebih teliti dan lebih berhati - hati dalam menyimpan material proyek agar di tempatkan di tempat yang layak seperti gudang. Gudang yang disediakan harus memenuhi peraturan K3 konstruksi yaitu aman, nyaman dan bersih sehingga material terjaga dengan baik dan tidak membahayakan kesehatan para pekerja.

b. Pekerja konstruksi harus selalu memakai safety tools saat bekerja, untuk menghindari iritasi dan luka yang disebabkan oleh material.

\section{Pengendalian K3 Peralatan}

a. Pihak kontraktor harus menyediakan peralatan proyek yang sudah benar - benar aman untuk digunakan, agar tidak menganggu kesehatan para pekerja

b. Peralatan harus di simpan di tempat khusus/gudang dalam keadaan rapi dan bersih.

c. Penggunaan peralatan alat berat di kendalikan oleh oprator alat berat yang sudah ahli agar proyek berjalan dengan lancar.

\section{Pengendalian K3 Lingkungan Proyek}

a. Setiap pihak yang terkait pada proyek tersebut harus menjaga kebersihan di sekitarnya dan mentaati tata tertib yang berlaku.

b. Ketika keadaan darurat terjadi, setiap pihak pada proyek tersebut harus sigap untuk mengantisipasi resiko yang mungkin terjadi akibat keadaan darurat tersebut dengan menerapkan peraturan $\mathrm{K} 3$ kontruksi yang berlaku.

\section{DAFTAR PUSTAKA}

https://id.wikipedia.org/wiki/Kesehatan_dan_kese lamatan_kerja http://learnmine.blogspot.com/2015/04/kesel amatan-dan-kesehatan-kerja.html

http://sistemmanajemenkeselamatankerja.blogspo t.com/2013/09/pengertian- kecelakaankerja-dan-insiden.ht

http://www.gajimu.com/main/pekerjaanyanglayak/keselamatan-dan-kesehatankerja/pertanyaan-mengenai-k

http://www.slideshare.net/LadiieAdoniia/ruanglingkup-kesehatah-keamanan-dankeselamatan-kerja

http://www.academia.edu/5417700/HUKUHUK UM_KESEHATAN_DAN_KESELAMAT AN_KERJA_K3_Ma

http://digilib.uinsuka.ac.id/13319/2/BAB\%20I,\% 20V,\%20DAFTAR\%20PUSTAKA.pdf

Penerapan (K3L) Keselamatan Kesehatan Kerja

Dan Lingkungan Pada Pelaksanaan

Proyek Konstruksi Tower. -pondasi.html http://pu.bantulkab.go.id/berita/96-kolombangunan-pengertian-jenis-dan-fungsinya 